\title{
Erfaringar med dialektisk åtferdsterapi i Molde
}

\section{Eit kvalitetssikringsarbeid ved ein spesialpoliklinikk for pasientar med sjølvdestruktiv åtferd og emosjonell dysregulering.}

\author{
Ved Heidi Bjørnerem og Egil Jonsbu
}

\begin{abstract}
Det er ei stor utfordring å gi pasientar med kjenslemessig ustabilitet og sjølvdestruktiv åtferd eit godt behandlingstilbod. Dialektisk åtferdsterapi (DBT) er ein poliklinisk behandlingsmodell som har gitt gode resultat. DBT-poliklinikken i Molde er den første i sitt slag i Noreg. Vi ønskjer i dette arbeidet å evaluere våre pasientar i høve til komorbiditet, karakteristika for dei som deltok og dei som fall ut av behandlinga, endringar under behandling, samt å samanlikne pasientar med kort og lang behandlingstid. Pasientane blir evaluert i høve til alder, kjønn, diagnosar og psykometriske variablar.

Av 128 pasientar evaluert for DBT, starta 60 opp programmet. Pasientane vart diagnostisert med MINI og SCID-II, i tillegg til eigenvurderingar og terapeutvurderingar av psykometriske variablar. Det var høg grad av komorbiditet, og dei fleste hadde personlegdomsdiagnosar (80 \%). Fråfallprosent var låg $(20 \%)$. Dei som fall frå skilte seg lite frå behandlingsgruppa ved oppstart av behandlinga.

Behandlingsgruppa viste signifikant positiv endring for håpløyse, depresjon, livskvalitet, psykisk helse, skår for personlegdomsforstyrring og terapeutvurdert funksjons- og symptomskår. Dei med kort behandlingstid var yngre og hadde mindre eteforstyrringar. DBT-poliklinikk i Distrikts-Noreg synest å vere eit hensiktsmessig og godt behandlingstilbod for pasientar med kjenslemessig dysregulering og sjølvdestruktiv åtferd.
\end{abstract}

Offering proper treatment to people with emotional instability and self-destructive behaviour is a challenge. Dialectical Behavior Therapy (DBT) is an outpatient treatment that has proven effective. The DBT-outpatient clinic in Molde is the first of its kind in Norway. In this study we want to evaluate patients according to comorbidity, characteristics of those who attended and those who dropped out of treatment, changes during treatment, and differences by length of treatment.

Of 128 patients evaluated for DBT, 60 attended the programme. The patients were diagnosed by MINI and SCID II, in addition to self-evaluations and therapist assessments of psychiatric variables. The degree of comorbidity was high and most of the patients had personality disorders (80\%). Dropout was low (20\%). The dropouts showed little difference at the beginning of treatment from those who completed the treatment. The treatment group showed significant positive changes in hopelessness, depression, mental health, quality of life, personality disorder scores and therapist-assessed scores for symptoms and function. The patients who attended for a short time were younger and had lower prevalence of eating disorder

The DBT outpatient clinic seems to offer suitable and positive treatment for patients with emotional dysregulation and self-destructive behaviour in rural parts of Norway.

\section{Bakgrunn}

Menneske med emosjonelle reguleringsvanskar har brå og sterke kjensler. Desse kjenslene har dei vanskar med å tolerere, og dei kan impulsivt ty til sjølvskading, rus eller sjølvmordsforsøk for å oppnå kortvarig distraksjon eller lindring. På lengre sikt medfører dette åtferdsmønsteret store vanskar (Linehan, 1993). Pasientar med slikt vanskebilete kan heilt eller delvis oppfylle kriteria for emosjonelt ustabil personlegdomsforstyrring (Sosial og helsedirektoratet, ICD-10, 2004). Behandling av pasientar med slike vanskar er utfordrande på grunn av stadige kriser og svingande behandlingsmotivasjon. Pasientane har auka risiko for sjølvmord og død av andre årsaker (Hawton et al., 2006), og kostnadane for samfunnet er høge (van Asselt et al., 2007). Summen av desse faktorane har ført til stigmatisering og behandlingspessimisme for denne pasientgruppa (Aviram et al., 2006). Utfordringane har vore å lage behandlingsmodellar som er effektive og som pasientane aksepterer. Behandlingsfråfall for denne pasientgruppa er funne i området 16,7-77 \%
(Linehan et al.,1991; Verheul, 2003).

Med bakgrunn i dei omfattande problema til desse pasientane, er det ei generell oppfatning at dei treng langtidsbehandling, men nytten av dette er lite undersøkt. Dialectical Behavioral Therapy (DBT) er utvikla av Marsha Linehan (Linehan, 1993), primært for kvinner med emosjonelt ustabil personlegdomsforstyrring og parasuicidal åtferd. Behandlinga er basert på kognitiv terapi, læringsteori og har eit filosofisk grunnlag frå Zen og dialektikk. Sentralt i behandlinga er arbeidet med emosjonell regulering og utvikling av relasjonell kompetanse. Behandlinga kombinerer individualterapi og ferdigheitsopplæring i gruppe, samt eigentrening på nye ferdigheiter. I følgje ei dialektisk tenking prøver ein å balansere mellom å forvente endring og aksept hos pasienten. DBT har også eit sterkare fokus på pasient-terapeutrelasjonen enn det som er vanleg i kognitive eller åtferdsorienterte terapiar (Mehlum, 2001). Randomiserte kontrollerte studiar hos vaksne har vist god effekt av DBT for pasientar med emosjonell ustabil personlegdomsforstyrring og parasuicidal åtferd,

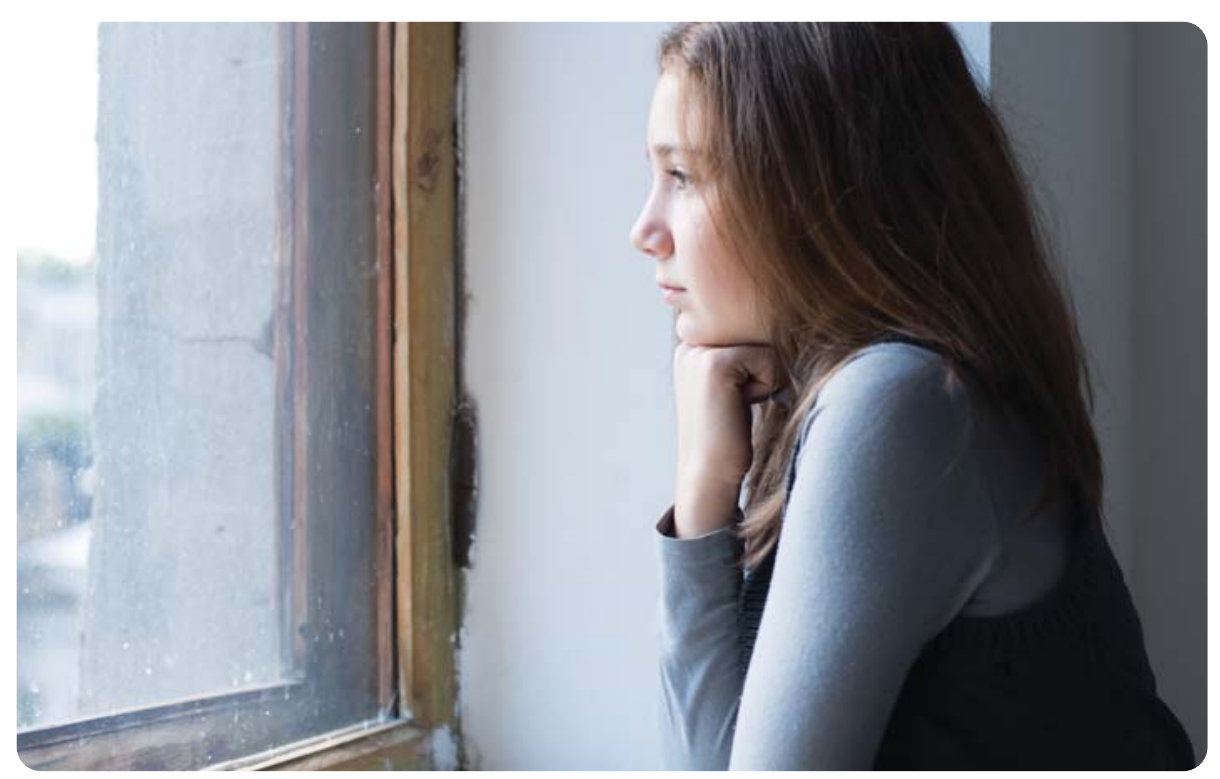


i form av mindre sjølvskading og sjølvmord, betre regulering av emosjonar og betre livskvalitet (Linehan et al., 2006; Stoffers et al., 2012). DBT er derfor anbefalt av internasjonale faginstitusjonar (NICE, 2009; APA, 2001).

På 80-talet vart det etablert ei langtidsavdeling for yngre menneske med emosjonelle reguleringsvanskar og sjølvdestruktiv åtferd i Møre og Romsdal. Delvis av økonomiske årsaker, og delvis på grunn av behov for ny tenking rundt denne pasientgruppa, vart avdelinga gradvis avvikla, og i 2007 erstatta av ein DBT-poliklinikk. Framleis er dette den einaste DBT-poliklinikken i Noreg. Det er ikkje tidlegare publisert norske studiar, som spesifikt evaluerer DBT. Det er viktig å evaluere korleis nye behandlingsprogram fungerer på eit norsk uselektert materiale.

\section{Problemstilling}

Med utgangspunkt i DBT-poliklinikken ønska vi å:

1) Gi ein oversikt over alle pasientane som byrja i DBT-programmet, i høve til personlegdomsforstyrringar, symptomdiagnosar og komorbiditet.

2) Samanlikne baseline-verdiar på dei pasientane som avslutta behandlinga utan avtale (fråfall) med dei som fullførte behandling etter avtale, i høve til kjønn, alder, personlegdoms- og symptom-diagnosar, håpløyse, depresjon, livskvalitet, psykisk helse, grad av personlegdomsforstyrring og terapeutvurdert funksjons- og symptomgradering.

3) Vurdere endringar under og etter behandlinga i høve til opplevd håpløyse, depresjon, livskvalitet, psykisk helse, grad av personlegdomsforstyrring og terapeutvurdert funksjons- og symptomgradering.

4) Samanlikne dei som hadde kort og lang behandlingstid i DBT-programmet, i høve til alder, diagnosar og endring av psykisk liding.

\section{Materiale og metode}

\section{Deltakarar}

Utgangspunktet for kvalitetssikringsstudien var pasientar frå Møre og Romsdal, som vart evaluert for DBT ved DBTpoliklinikken i Molde frå oppstart i mars 2007 til juni 2013.

\section{Inklusjonskriterier:}

1) Sjølvdestruktiv åtferd

2) Vanskar med emosjonell regulering

3) Over 18 år

4) Villig til forpliktande avtale

Sjølvdestruktiv åtferd er i denne studien definert som all form for eigenskade, utagering og uønskt sosial åtferd, med bakgrunn i vanskar med emosjonell regulering.

\section{Eksklusjonskriterier:}

1) Stort innslag av antisosiale trekk

2) Rusmisbruk som hovudproblem

3) Pågåande psykose

4) Depresjon med lav fungering

5) Betydeleg kognitiv og/eller språkleg svikt

6) Body mass index mindre enn 17

Terapeut vurderte i samarbeid med dei andre terapeutane ved DBT-poliklinikken om inklusjonskriteria var oppfylt. Totalt blei 128 pasientar vurdert for inklusjon, 60 tilfredsstilte kriteria. Av desse fullførte 48 DBT-programmet heilt ("Fullførte DBT"), eller delvis (slutta etter avtale). Tolv byrja, men slutta utan avtale ("Fråfallsgruppa"), og desse hadde derfor inga vurdering etter baseline.

\section{Behandling og evaluering}

Pasientane i DBT-programmet hadde individuell samtale (1 time) og ferdigheitsgruppe (2,5 timar) kvar veke, og skulle i tillegg øve på ferdigheiter mellom timane. Behandlarane (lege, psykolog, psykiatrisk sjukepleiar og klinisk sosionom) hadde som minimum intensivkurs i DBT (5-10 dagar kurs, med sjølvstudium og eksamen) og deltok i felles rettleiing i DBT.
Normal behandlingstid er eit år, men i praksis måtte vi tilpasse behandlingstida individuelt. Nokre pasientar forplikta seg berre for nokre månader, medan andre ønska vidare individuell behandling etter det første året. Det var derfor stor spreiing i kor lenge pasientane deltok i behandlinga, frå nokre månader til tre år.

\section{Design}

Etter planen skulle pasientane evaluerast ved start, etter 6, 12 og 24 månader, samt ved behandlingsslutt. Ved gjennomgang mangla vi mange data, særleg ved dei siste måletidspunkta (Figur 1). For å evaluere endringar i symptom og funksjonar hos gruppa som fullførte DBT-programmet, samanlikna vi utgangsverdiane ("start") med den siste evalueringa for den enkelte pasient ("siste"), median (min-max) oppfølgingstid var 12 mnd. (3-40). Designet med varierande oppfølgingstid blei vald for å få med flest mogeleg pasientar med lengst mogeleg oppfølgingstid. Nokre av pasientane var framleis i programmet da vi oppsummerte evalueringane.

Da vi samanlikna pasientane med lang og kort behandlingstid, vurderte vi berre dei som hadde avslutta behandlinga $(\mathrm{N}=41)$.

Figur 1.

$n=48$

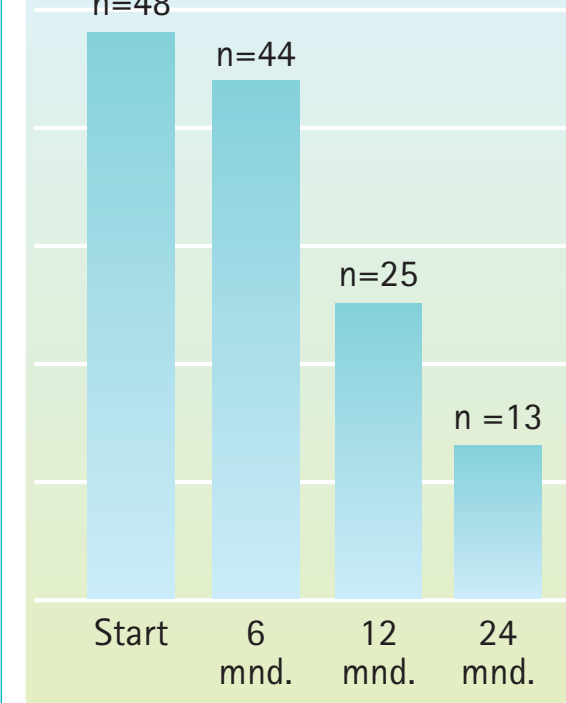


Pasientane blei vurdert i høve til personlegdomsdiagnosar (akse II) og symptomdiagnosar (akse I) i DSM-IV. Alle behandlarar gjorde diagnostikk. Dei med treårig utdanning har fått intern opplæring, og deira diagnosesetting blei drøfta med overlege. Psykologane drøfta diagnosesetting med psykologspesialist. Var det usemje om diagnostikk, vart det drøfta i fellesskap, og endeleg bestemt av overlegen. Resultatet av diagnosesettinga blei formidla til pasientane.

\section{Diagnostisk verktøy}

Vurdering i høve til personlegdomsdiagnosar (akse II) vart gjort med Personality Diagnostic Questionnaire for DSM - 4th Edition (PDQ-4) (Hyler, 1990), som er eit sjølvutfyllinginstrument. Ved sumskår over 30 blei pasientane intervjua med Structured Clinical Interview for DSM-IV Axis II Personality Disorders (SCID-II) (First et al., 1990). DSM-IV symptomdiagnosar (akse I) blei vurdert ved MINI Internasjonalt Nevropsykiatrisk Intervju, norsk versjon 5.0.0 (Leiknes et al., 1999).

\section{Evalueringsverktøy}

Personality Diagnostic Questionnaire for DSM- 4th Edition (PDQ-4) vart brukt som screening for personlegdomsforstyrring og som endringsvariabel. Opplevd håpløyse og motivasjon vart vurdert med Beck Hopelessness Scale (BHS) (Beck \&t Steer, 1988); eit spørjeskjema med 20 sant/usant-utsegn, med sumskår 0-20, der høgt tal betyr stor håpløyse. Depresjon og negative tankar blei undersøkt ved Beck Depression Inventory (BDI) (Beck, 1961); eit spørjeskjema med 21 spørsmål med skåring 0-3 for kvart spørsmål, der 0-9 indikerer ingen depresjon, 10-18 mild-moderat depresjon, 19-29 moderatalvorleg depresjon og 30-63 alvorleg depresjon. Livskvalitet blei vurdert med WHO Quality of Life - Bref (WHOQOL Bref, 1996; Hanestad et al, 2004); der to generelle spørsmål omhandlar livskvalitet og helse, begge gradert 1-5.
Resten av dei 26 spørsmåla er gruppert i fire domene: fysisk helse, psykisk helse, sosiale relasjonar og omgivnader. Enkeltspørsmål er gradert 1-5, og sumskår blir konvertert til skala 1-100. Høge skår er uttrykk for høg tilfredsheit. I evalueringa har vi vurdert livskvalitet og psykisk helse som mest relevante parametrar å bruke. Behandlar vurderte funksjonsnivå med Global Assessment of Functioning, split version (GAF-F/GAF-S) (Karterud et al., 1998); der behandlar vurderte grad av funksjon (GAF-F) og symptom (GAF-S) på skala 0-100, der høgt tal svarar til høg funksjon/lite symptom.

\section{Etikk}

Studien blei lagt fram for Regional Etisk Komité Midt-Noreg, som vurderte det som eit kvalitetssikringsprosjekt, som ikkje trong godkjenning. Alle pasientane ga skriftleg godkjenning til at han/ho kunne bli kontakta for evaluering etter avslutta behandling.

\section{Statistikk}

Samanlikning mellom gruppene blei gjort ved hjelp av Mann-Whitney U-test for kontinuerlege variablar (pga. små grupper) og khikvadrattest for dikotome data. Endring av psykometriske variablar blei analysert ved hjelp av paret t-test. Alfa-nivå var $p<0.05$. SPSS versjon 21 blei brukt i analysane.

\section{Resultat}

\section{Symptom-og personlegdoms- diagnostikk}

Det var høg grad av komorbiditet. Dei fleste pasientane som byrja i DBT hadde ein eller fleire personlegdomsdiagnosar (80 \%), med emosjonelt ustabil (48\%) og unnvikande personlegdomsforstyrring (23\%) som dei vanlegaste (tabell 1). Alle hadde minst ein symptomdiagnose, med depresjon/dystymi (85 \%) og eteforstyrring $(57 \%)$ som dei vanlegaste (tabell 1).

Samanlikning mellom dei som fullførte DBT-programmet og dei som slutta utan avtale

Andelen fråfall var 12/60 (20 \%).

Analysene viste ingen statistisk signifikant forskjell mellom gruppene (tabell 2 neste side).

Tabell 1. Komorbiditet blant pasientane i studien $(\mathrm{N}=60)$

\begin{tabular}{|l|r|r|r}
\hline Diagnosar & $\begin{array}{c}\text { Alle som } \\
\text { byrja i DBT, } \\
\text { N=60 (\%) }\end{array}$ & $\begin{array}{c}\text { Pasientar med } \\
\text { emosjonell } \\
\text { ustabil PF, } \\
\mathrm{n=29}(\%)\end{array}$ & $\begin{array}{c}\text { Pasientar utan } \\
\text { emosjonell } \\
\text { ustabil PF, } \\
\mathrm{n=31}(\%)\end{array}$ \\
\hline Unnvikande PF & $14(23 \%)$ & $7(24 \%)$ & $7(23 \%)$ \\
\hline Anna PF & $14(23 \%)$ & $2(7 \%)$ & $12(39 \%)$ \\
\hline Ingen PF & $12(20 \%)$ & & $12(39 \%)$ \\
\hline Dystymi/Depresjon & $51(85 \%)$ & $27(93 \%)$ & $24(77 \%)$ \\
\hline Eteforstyrring & $34(57 \%)$ & $17(59 \%)$ & $17(55 \%)$ \\
\hline Fobi/Angst & $38(63 \%)$ & $19(66 \%)$ & $19(61 \%)$ \\
\hline Generalisert angstliding & $15(25 \%)$ & $4(14 \%)$ & $11(36 \%)$ \\
\hline Posttraumatisk stressliding & $11(18 \%)$ & $8(28 \%)$ & $3(10 \%)$ \\
\hline Obsessiv kompulsiv liding & $4(7 \%)$ & $1(4 \%)$ & $3(10 \%)$ \\
\hline Alkohol/hasj-misbruk & $10(17 \%)$ & $8(28 \%)$ & $2(7 \%)$ \\
\hline
\end{tabular}

PF, personlegdomsforstyrring 
Tabell 2. Samanlikning av sosiodemografiske og kliniske karakteristika for "Fullførte DBT" og "Fråfallsgruppa" ved baseline.

\begin{tabular}{|c|c|c|c|}
\hline & $\begin{array}{l}\text { Fullførte } \\
\text { DBT } n=48\end{array}$ & $\begin{array}{l}\text { Fråfalls- } \\
\text { gruppa } n=12\end{array}$ & p-verdi \\
\hline Kvinneandel, n (\%) & $42(88 \%)$ & $11(91 \%)$ & $1,0 a$ \\
\hline Alder i år, median (min-max) & $26,2(17-61)$ & $22,3(19-32)$ & $0,3 b$ \\
\hline Personlegdomsforstyrringar, snitt (SD) & $1,0(0,8)$ & $1,0(0,4)$ & $0,6 b$ \\
\hline Symptomdiagnosar, snitt (SD) & $2,7(1,3)$ & $2,1(1,0)$ & 0,16 \\
\hline Beck Hopelessness Scale, snitt (SD) & $12(5,4)$ & $14(5,6)$ & $0,2 b$ \\
\hline Beck Depression Inventory, snitt (SD) & $27(9,3)$ & $31(7,9)$ & $0,1 b$ \\
\hline Livskvalitet (WHOOOL-bref), snitt (SD) & $2,3(0,80)$ & $2,5(0,52)$ & 0,16 \\
\hline Psykisk helse (WHOQOL-bref), snitt (SD) & $27(11,5)$ & $29(11,3)$ & $0,4 b$ \\
\hline $\begin{array}{l}\text { Personality Diagnostic Questionnaire } \\
\text { for DSM-4'th edition, snitt (SD) }\end{array}$ & $42(12,7)$ & $46(10,8)$ & $0,2 b$ \\
\hline $\begin{array}{l}\text { Global Assessment of Functioning - } \\
\text { Function, snitt (SD) }\end{array}$ & $53(10,0)$ & $52(7,6)$ & $0,7 b$ \\
\hline $\begin{array}{l}\text { Global Assessment of Functioning - } \\
\text { Symptom, snitt (SD) }\end{array}$ & $52(6,3)$ & $49(7,4)$ & $0,08 b$ \\
\hline
\end{tabular}

\section{a Fishers Exact Test $\quad$ b Mann-Whitney U-test}

Tabell 3. Endring i håpløyse, depresjon, livskvalitet, psykiske helse, personlegdomsskår, og terapeutvurdert funksjons- og symptomskår frå start av behandling til siste måling (paret t-test).

\begin{tabular}{|c|c|c|c|}
\hline & $\begin{array}{l}\text { Start } \\
\text { Snitt (SD) }\end{array}$ & $\begin{array}{l}\text { Siste } \\
\text { Snitt (SD) }\end{array}$ & p-verdi \\
\hline Beck Hopelessness Scale, $n=43$ & $11(5,4)$ & $6(5,2)$ & $<0,001$ \\
\hline Beck Depression Inventory, $\mathrm{n}=45$ & $27(9,5)$ & $13(9,9)$ & $<0,001$ \\
\hline Livskvalitet, (WHOQOL-bref), $n=46$ & $2,3(0,8)$ & $3,4(1,0)$ & $<0,001$ \\
\hline Psykisk helse, (WHOQOL-bref), $n=47$ & $27(11)$ & $50(22)$ & $<0,001$ \\
\hline $\begin{array}{l}\text { Personality Diagnostic Questionnaire } \\
\text { for DSM-4'th edition, } n=33\end{array}$ & $42(11)$ & $28(14)$ & $<0,001$ \\
\hline $\begin{array}{l}\text { Global Assessment of Functioning } \\
\text { - Function, } n=43\end{array}$ & $53(9.9)$ & $68(11)$ & $<0,001$ \\
\hline $\begin{array}{l}\text { Global Assessment of Functioning } \\
\text { - Symptom, } n=43\end{array}$ & $52(5,9)$ & $68(10)$ & $<0,001$ \\
\hline
\end{tabular}

Endring av psykometriske variablar fro̊ start til siste måling

Samanlikning av psykometriske variablar for "Fullførte DBT" mellom start av behandling og siste måling er vist $i$ tabell 3 . Det er ved siste måling signifikant $(p<0.001)$ positiv endring for alle variablane som er evaluert; håpløyse (BHS) og depresjon (BDI), livskvalitet og psykisk helse (WHO0OL-Bref), skala for evaluering av personlegdomsforstyrring (PDQ-4) og terapeutvurdert funksjons- (GAF-F) og symptom-skår (GAF-S) (tabell 3).
Samanlikning mellom pasientane med kort og lang behandlingstid

Samanlikning mellom dei av deltakarane som deltok tre til seks månader i DBTprogrammet $(n=12)$, og dei som deltok meir enn 18 månader $(n=13)$ er vist $\mathrm{i}$ tabell 4. Dei som deltok kortast, var yngre ( $p=0,03$, Mann-Whitney U-test), og færre av dei hadde eteforstyrringar ( $p=0,004$, Fishers Exact Test). (Tabell 4 neste side)

\section{Diskusjon}

Hovudfunn i studien er: Det var høg grad av komorbiditet hos dei som byrja i DBT; $80 \%$ hadde ein eller fleire personlegdomsdiagnosar, og alle hadde minst ein symptomdiagnose. Kvinneandelen var på $88 \%$. Berre $20 \%$ av dei som starta i DBT-programmet fall frå. Dei som fall frå, skilte seg lite ved start av behandlinga frå dei som følgde programmet. Pasientane opplevde statistisk signifikant betring i høve til opplevd håpløyse, depresjon, livskvalitet, psykisk helse, skala for evaluering av personlegdomsforstyrring og terapeutvurdert funksjons- og symptomskår. Dei pasientane som gjekk kortast i DBT-programmet var yngre og hadde mindre eteforstyrringar.

Hos dei som byrja i DBT-programmet $(\mathrm{N}=60)$ var det $\mathrm{h} ø \mathrm{~g}$ grad av komorbiditet. Åtti prosent hadde ein eller fleire personlegdomsdiagnosar, og $48 \%$ fylte kriteria for emosjonelt ustabil personlegdomsforstyrring. I tillegg fann vi at dei hadde gjennomsnittleg 2,7 symptomdiagnosar. Det er kjent frå tidlegare studiar at pasientar med emosjonelt ustabil personlegdomsforstyrring har høg grad av komorbiditet med symptomdiagnosar, og at komorbiditet gjer behandlinga meir utfordrande (Zanarini et al., 2004). Andelen eteforstyrringar var $57 \%$. Dette var erkjent problematikk for nokre pasientar, men for andre vart denne diagnosen avdekka gjennom diagnostisk intervju. Det er derfor viktig å ha fokus på eteforstyrring i behandlingstilbodet til pasientar med emosjonell dysregulering. 
Tabell 4. Samanlikning av pasientane med kort og lang behandlingstid i DBT.

\begin{tabular}{|c|c|c|}
\hline & $\begin{array}{l}\text { 3-6 månader } \\
\text { i terapi } n=12\end{array}$ & $\begin{array}{l}>18 \text { månader } \\
\text { i terapi } n=13\end{array}$ \\
\hline Alder, median (min-max) & $20(17-28)$ & $26(19-61)$ \\
\hline Personlegdomsforstyrringar baseline, snitt (SD) & $0,8(0,7)$ & $0,6(0,7)$ \\
\hline $\begin{array}{l}\text { Emosjonelt ustabil personlegdomsforstyrring ved } \\
\text { start, } n(\%)\end{array}$ & $7(58)$ & $4(31)$ \\
\hline $\begin{array}{l}\text { Unnvikande personlegdomsforstyrring ved start, } \\
\mathrm{n}(\%)\end{array}$ & $2(17)$ & $2(15)$ \\
\hline Symptomdiagnosar ved start snitt (SD) & $2,7(1,6)$ & $3,0(0,7)$ \\
\hline Eteforstyrringar ved start, $\mathrm{n}(\%)$ & $4(33)$ & $12(92)$ \\
\hline $\begin{array}{l}\text { Angstlidingar (Generalisert angstliding, panikk- } \\
\text { angst, fobi, posttraumatisk stressliding, } \\
\text { obsessiv-kompulsiv liding) ved start, snitt (SD) }\end{array}$ & $1,3(1,0)$ & $1,1(0,9)$ \\
\hline Depresjon/Dystymi ved start, n (\%) & $10(83)$ & $12(92)$ \\
\hline Beck Hopelessness Scale & $7,1(4,5)^{*}$ & $3,8(9,2)^{*}$ \\
\hline Beck Depression Inventory & $17,3(11,6)^{*}$ & $8,9(8,9)^{*}$ \\
\hline Livskvalitet (WHOQOL-Bref) & $-1,0(0,9)^{*}$ & $-1,3(1,3)^{*}$ \\
\hline Psykisk helse (WHO0OL-Bref) & $-24(23)^{*}$ & $-25(19)^{*}$ \\
\hline $\begin{array}{l}\text { Personality Diagnostic Questionnaire for } \\
\text { DSM-4'th edition }\end{array}$ & $19(9)^{*}$ & $11(12)^{*}$ \\
\hline Global Assessment of Functioning - Function & $-15(10)^{*}$ & $-17(10)^{*}$ \\
\hline Global Assessment of Functioning - Symptom & $-18(11)^{*}$ & $-19(9)^{*}$ \\
\hline
\end{tabular}

\section{*Estimator; differansen mellom baselineverdi og siste måling (snitt SD).}

Våre funn tyder på at pasientane ved vår spesialpoliklinikk har komplekse og alvorlege problem, der systematisk tilnærming og strukturert DBT-behandling kan vere eit godt eigna behandlingstilbod (Harned et al., 2008).

Den høge kvinneandelen (88 \%) i vårt utval stemmer godt med tilsvarande undersøkingar av pasientar med emosjonelle reguleringsvanskar. DBT vart utvikla nettopp for kvinner med emosjonelt ustabil personlegdomsforstyrring og parasuicidal åtferd (Linehan et al., 1991).

Verheul et al. (2003) samanlikna DBT med vanleg behandling og fann lågare fråfall i DBT-gruppa ( $27 \%$ vs. $77 \%$ ). Linehan et al. (1991) hadde fråfall på 16,7 \% i sin første randomiserte kontrollerte studie på DBT. Vår studie, med fråfall på $20 \%$, bekreftar dette låge fråfallnivået. Motivasjons- og forpliktingsarbeid er sentralt i heile forløpet i DBT, særleg hos dei yngste. Resultata våre kan tyde på at vi har lukkast godt med dette.

Endringane frå start av behandlinga til siste måling, i høve til opplevd håpløyse (BHS), depresjon (BDI), livskvalitet og psykisk helse (WHOOOL-Bref), skala for evaluering av personlegdomsforstyrring (PDQ-4) og terapeutvurdert funksjonsog symptomskår (GAF) var både statistisk og klinisk signifikante. DBT har ved tidlegare studiar med kontrollgruppe vist seg å vere ei effektiv behandling for den aktuelle pasientgruppa (Harned et al., 2008), og endringane i vår studie liknar på endringane i samanliknbare studiar (Koons et al., 2001; Turner, 2000).
Dei positive endringane av symptom og funksjonar hos dei som deltok i DBT-programmet må sjåast i samanheng med at dei som starta i behandlinga var motiverte og villige til å inngå behandlingsavtale.

Det kan verke litt overraskande at positive endringar tenderte til å vere større hos den gruppa som hadde gått kortast, trass $i$ at dei hadde noko høgare førekomst av emosjonelt ustabil personlegdomsforstyrring og var yngre. Dette passar likevel godt med våre kliniske erfaringar; unge pasientar med store emosjonelle reguleringsvanskar kan ha god nytte av eit slikt strukturert behandlingstilbod, sjølv om dei ikkje er motiverte for langtidsbehandling. Desse resultata tydar på at ei vidareutvikling av DBT-poliklinikkar for ungdom kan vere ein veg å gå (Miller et al., 2007).

Unnvikande personlegdomsforstyrring er ei utfordring å behandle. Pasientane unngår effektive element $\mathrm{i}$ behandlinga fordi det er ubehageleg. Vi hadde ein tanke om at unnvikande personlegdomsforstyrring kunne vere overrepresentert blant dei som gjekk lengst $\mathrm{i}$ behandling. Denne hypotesen blei ikkje bekrefta.

Meir eteforstyrringar i gruppa som gjekk lengst (12 av 13 pasientar) stemmer med våre erfaringar; dei som har eteforstyrringar treng lenger tid til endring, særleg ved samstundes personlegdomsforstyrring, noko som også er vist tidlegare

(Rosenvinge et al., 2000). Dei med lengst behandlingstid hadde høgare alder, samstundes som dei tenderte til mindre positiv endring under behandlinga. Det kan tyde på at det er lettare å endre mønster i tidleg vaksen alder, enn seinare i livet.

Ein nederlandsk studie (Aviram et al., 2006) viser at menneske med emosjonelt ustabil personlegdomsforstyrring kostar samfunnet store summar, dersom dei ikkje får adekvat behandling. Det er i dag konsensus i aktuelle fagmiljø om at langvarig avdelingsopphald er uheldig for denne 
pasientgruppa (Sosial- og helsedirektoratet, 2008), og at dei bør møtast på ein aktiv og utforskande måte så tidleg som mogeleg (Paris, 2007). Fleire studiar viser at DBT er kostnadseffektiv, også i høve til andre psykoterapiformer (Pasieczny \&t Connor, 2011).

\section{Styrker og svakheiter ved studien}

Styrken med studien er at den vurderer alle pasientane som blei evaluert for DBT i det aktuelle tidsrommet. Det er også ein styrke at evalueringa bygger både på sjølvutfyllingsskjema og terapeutvurdering. Ei svakheit er at studien manglar kontrollgruppe. Gruppene, der vi samanliknar kort og lang behandlingstid, er små $(\mathrm{N}=12+13)$, og verdien av funna er derfor usikker. Det er også ei metodisk svakheit at både behandlingstida og oppfølgingstida varierer blant pasientane. DBT har i tidlegare studiar vist god effekt på sjølvskading, sjølvmordsåtferd, sjukehusinnleggingar og liknande åtferdsmål (Linehan et al., 1991, 2006; Verheul, 2003; Turner, 2000; Koons, 2001). Dessverre er ikkje slike åtferdsmål registrert systematisk i denne studien.

\section{Hypotesar for seinare studiar}

Vårt arbeid gir idear om nye studiar på DBT for pasientar under 18 år, for å undersøke om ei slik tilnærming kan hindre kronifisering av emosjonell dysregulering og sjølvdestruktiv åtferd.

Vi får også tankar om vidareutvikling av DBT- program for spesifikk komorbiditet, som til dømes eteforstyrringar og unngåingsåtferd.

\section{Konklusjon}

DBT-poliklinikk synest å vere eit hensiktsmessig og godt behandlingstilbod til pasientar med emosjonelle reguleringsvanskar og sjølvdestruktiv åtferd i Distrikts-Noreg.

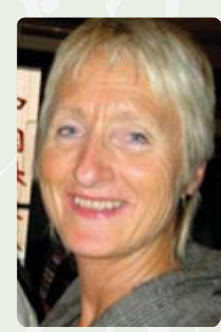

Heidi Bjørnerem lege, spesialist i barneungdoms- og vaksenpsyki-atri. Overlege på DBT-poliklinikken R.O.B.U.S.T. ved Psykiatrisk poliklinikk i Molde, Helse Møre og Romsdal.

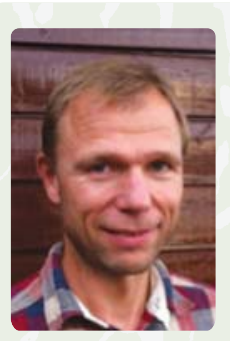

Egil Jonsbu, lege, spesialist i psykiatri, Phd. Overlege ved Klinikk for vaksenpsykiatri, Molde sjukehus, Helse Møre og Romsdal / førsteamanuensis NTNU.

Forfattaren har ingen interessekonfliktar i høve ti artikkelen og har ikkje mottatt økonomisk støtte.

\section{Litteratur}

American Psychiatric Association (APA). (2001). Practice guideline for the treatment of patients with borderline personality disorder. Guideline watch.

Asselt van A.D.I. et al. (2007). Cost of Borderline Personality Disorder: Societal Cost of illness in BPD-patients. Eur Psychiatry, 22(6): 54-61.

Aviram R.B. et al. (2006). Borderline Personality Disorder, Stigma, and Treatment Implications. Harv Rev Psychiatry, vol 14, no 5: 249-56.

Beck A. et al. (1961). An inventory for measuring depression. Arch.Gen. Psychiatry. 4(6): 561-71.

Beck A., Steer R. (1988). Beck Hopelessness Scale manual. San Antonio, TX: Psychological Corporation.

First M.B. et al. (1990). Structured Clinical Interview for DSM-IV Axis II Personality Disorders, (SCID-II). Washington, D.C.: American Psychiatric Press, Inc.

Hanestad B.R. (2004). Psychometric properties of the WHOQOL-BREF Questionnaire for the Norwegian general population. J Nurs Meas 12 (2): 147-59.

Harned M.S. et al. (2008). Treating Co-Occuring Axis I Disorders in recurrently Suicidal Women with Borderline Personality Disorder: A 2-Year Randomized Trial of Dialectical Behavior Therapy versus Commonly Treatment by Experts. J Consult Clin Psychol. vol 76, no 6: 1068-75.

Hawton K. et al. (2006). Deaths from all causes in a long-term follow-up study of 11583 deliberate self-harm patients. Psychol Med, 36: 397-405. Hyler S.E. (1990). Personality Diagnostic Questionnaire-4. New York: New York State Psychiatric Institute.

Karterud S. et al. (1998). S-GAF: Global funksjonsskåring - Splittet versjon. Bakgrunn og skåringsveiledning. Oslo: Klinikk for psykiatri, Ullevål sykehus.
Koons C.R. et al. (2000). Efficacy of Dialectical Behavior Therapy in Women Veterans With Borderline Personality Disorder. Behav Ther. 32 : 371-90.

Leiknes K.A. et al. (1999). MINI Internasjonalt Nevropsykiatrisk Intervju, 5.0.0. Norsk utgave. Oslo: Psykosomatisk avdeling, Rikshospitalet.

Linehan M.M. et al. (1991). Cognitive-behavioral treatment of chronically parasuicidal borderline patients. Arch. Gen. Psychiatry, 48: 1060-64.

Linehan, M.M. (1993). Cognitive Behavioral Treatment of Borderline Personality Disorder. New York: Guilford Press.

Linehan M.M. et al. (2006). Two-Year Randomized Controlled Trial and Follow-up of Dialectical Behavior Therapy vs Therapy by Experts for Suicidal Behaviors and Borderline Personality Disorder. Arch Gen Psychiatry, 62: 1-10.

Mehlum, L. (2001). Suicidal behaviour and personality disorder. Curr Opin Psychiatry, 14: 131-5.

Miller A.L. et al. (2007). Dialectical Behavior Therapy with Suicidal adolescents. New York: Guilford Press.

National Institute for Health and Clinical Excellence (NICE). (2009) Borderline personality disorder: treatment and management.

Paris J. (2007). Half in Love with Death. Managing the Chronically Suicidal Patient. London: Routledge.

Pasieczny N., Connor J. (2011). The effectiveness of dialectical behaviour therapy in routine public mental health settings: An Australian controlled trial. Behav Res Ther. 49: 4-10.

Rosenvinge J.H. et al. (2000). The comorbidity of eating disorders and personality disorders: a meta-analytic review of studies published between 1983 and 1998. Eat Weigth Disord. 5(2): 52-61.

Sosial- og helsedirektoratet. (2004). Den internasjonale klassifikasjonen av sykdommer og beslektede helseproblemer. (ICD-10). Oslo: Sosialog helsedirektoratet.

Sosial- og helsedirektoratet. (2008). Nasjonale retningslinjer for forebygging av selvmord i psykisk helsevern. Oslo: Sosial- og helsedirektoratet.

Stoffers J.M. et al (2012). Psychological Therapies for People with Borderline Personality Disorder. The Cochrane Library 15 aug.

Turner R.M. (2000). Naturalistic Evaluation of Dialectical Behavior Therapy - Oriented Treatment for Borderline Personality Disorder. Cogn Behav Practice. no 7: 413-19.

Verheul R. (2003). Dialectical Behaviour Therapy for Women with Borderline Personality Disorder, 12-month, Randomised Clinical Trial in The Netherlands. Br J Psychiatry, 182: 135-40.

WHOOOL - Bref. (1996). Introduction, administration, scoring and generic version of the assessment. Field Trial Version. Genèva: WHO.

Zanarini M.C. et al. (2004). Axis I Comorbidity in Patients With Borderline Personality Disorder: 6-Year Follow-Up and Prediction of Time to Remission. Am J Psychiatry. 161: 2108-14. 